\title{
Durability of concrete incorporating crushed brick as coarse aggregate
}

M. Adamson ${ }^{1}$, A. Razmjoo ${ }^{2}$ and A. Poursaee ${ }^{3 *}$

${ }^{1}$ Former Graduate Research Assistant, Glenn Department of Civil Engineering, Clemson University, Clemson, South Carolina, USA, 29634

Currently at United Consulting, Norcross, GA

${ }^{2}$ Former Graduate Research Assistant, Glenn Department of Civil Engineering, Clemson University, Clemson, South Carolina, USA, 29634

Currently at Griffin Dewatering, Houston, TX

${ }^{3}$ Assistant Professor, Glenn Department of Civil Engineering, Clemson University Clemson, South Carolina, USA, 29634

"Corresponding author:

Tel: (864)656-3323

email:amire@clemson.edu 


\begin{abstract}
Using crushed bricks as coarse aggregates in concrete is of particular interest to preserve natural aggregate sources as well as to reduce waste and waste storage. The objective of this experimental work was to study the durability of reinforced concrete made with crushed brick as aggregate. For this purpose, a comparative study was performed on the durability properties of concrete made with crushed brick as coarse aggregates and with natural aggregates. Results show that the natural coarse aggregates can be replaced by crushed bricks, without significant change in the durability of concrete when the steel is not present. However, when concrete is reinforced with steel, replacing natural aggregates with crushed brick is not recommended.
\end{abstract}

Key words: Crushed brick; Corrosion; Durability; Impedance 


\section{Introduction}

Construction and demolition waste is estimated to constitute $10 \%$ to $30 \%$ of all waste that enters landfills in the United States; of that debris, the dominant source by weight is asphalt, brick, and concrete [1]. Since bricks are a dominant material in residential construction $[2,3]$, they account for a large proportion of construction and demolition waste [4, 5]. In a recent study, it is estimated that the brick will remain the second most significant building material after concrete [3] over the next 50 years. Bricks are considered as waste when broken or damaged from the brick production line or from construction and demolition sites [4-6]. Previous studies have shown that brick and concrete waste can constitute up to $75 \%$ of construction and demolition waste from a construction site $[4,5]$. By recycling any of these components, a demolition project would take large steps toward reducing the amount of waste that goes into landfills [7]. In the past, efforts have been made to recycle some of these materials as base filler for road construction and other non-structural uses [8]. A study by Lennon [7] showed that recycling one ton of concrete, brick, and block costs approximately $\$ 21 /$ ton, while landfilling one ton of the same would cost approximately \$136/ton. As landfill space and natural aggregate become more costly in some markets in the United States [9], it is likely that the use of recycled aggregates including construction and demolitions, particularly recycled crushed brick, in concrete applications will increase as well.

Using crushed bricks as aggregates in concrete is of particular interest to preserve natural aggregate sources as well as to reduce waste and waste storage. The first use of crushed brick with portland cement was recorded in Germany in 1860 for the manufacturing of concrete products $[10,11]$. However, the first significant use of crushed brick as aggregates in new 
concrete has been recorded for reconstruction after the Second World War [12]. Brick masonry has long been used as a reliable building material in the United States. However, according to an industry survey, approximately $11.5 \mathrm{~kg} /$ ton of brick produced are dumped in landfills and are not recycled back into production [13]. Considering the world annual production of clay bricks which is approximately $6.25 \times 10^{8}$ ton [14], about $7 \times 10^{6}$ ton bricks go to the landfills each year. One solution to this problem could be recycling the waste bricks, either excess new bricks, or waste from demolished structures, and using them as aggregates in concrete. With increased environmental awareness during the past decades and economic motivations to reuse waste, use of masonry rubble is once again receiving attention.

Nevertheless, generally, the lack of knowledge of performance of concrete made with brick as its aggregates is an obstacle for reuse of brick waste in concrete [15]. Most of the studies on the use of crushed bricks as aggregates in concrete were focused on mechanical performance of such concrete structures. Some studies showed that the use of brick aggregate as a substitute for granite aggregates results in a loss of compressive strength [16-19]. This loss of strength is to the order of $10-35 \%$ for coarse aggregates, and $30-40 \%$ for fine aggregates, depending on the rate at which the brick was substituted for natural aggregates. However, with this decrease in compressive strength, a gain of about $11 \%$ is made for tensile strength, compared to concrete made with natural aggregates [20]. On the other hand, another study showed that the 28-day compressive strength of concrete made with crushed brick exceeded that of concrete made with natural granite aggregate and their values were virtually identical [18]. While the high porosity of brick particles contributes to higher permeability, it is expected that the porosity of the particles potentially improves the performance in freeze-thaw testing. Most studies in this area 
have been performed on brick particles used as a partial replacement for fine aggregate. It is found that incorporation of brick as fine aggregates with high porosity to mortar and concrete mixtures can improve the freeze-thaw resistance of the mixtures due to providing a similar air entraining action [21-24]. However, as far as the authors concern, no study was conducted on the behavior of concrete made with crushed brick as coarse aggregates in the freezing and thawing conditions.

Corrosion is the other important durability issue in steel reinforced concrete structure which is mainly the result of depassivation of the steel due to the ingress of chloride ions [25]. Consequently, it is important to consider a concrete's ability to resist chloride penetration. However, number of studies on the chloride diffusion into concrete made with brick aggregates is very limited. Kibriya and Speare [26] studied the chloride ion diffusion in concrete made with brick and natural aggregates and found that the chloride diffusivity of the concrete with brick aggregates was greater than that in the control specimens with natural aggregates. On the contrary, the result of the tests conducted by Cavalline showed that the brick concrete mixtures exhibit fairly good results in chloride ion permeability testing [27].

The objective of this work was to study the durability of the concrete made with crushed brick as partial replacement for natural aggregates. Mechanical properties, freeze-thaw durability, chloride permeability, electrical properties as well as corrosion of reinforcing bars in the samples were studied and evaluated. 


\section{Materials}

Partial coarse aggregate replacement was chosen in this study. A flat graded coarse aggregate was chosen rather than blending the sizes to a particular grade aggregate which guaranteed more uniformity in aggregate size in all samples. The brick aggregates were obtained by crushing new clay bricks with chemical composition shown in Table 1. New bricks were chosen to provide consistency and to minimize possible contaminants.

Table 1. Chemical compositions of the portland cement and clay brick

\begin{tabular}{ccc}
\hline Chemical Analysis (\%) & Portland cement & Clay brick \\
\hline $\mathrm{SiO}_{2}$ & 20.6 & 69.43 \\
$\mathrm{Al}_{2} \mathrm{O}_{3}$ & 5.1 & 17.29 \\
$\mathrm{Fe}_{2} \mathrm{O}_{3}$ & 3.4 & 6.4 \\
$\mathrm{CaO}$ & 64.5 & 0.51 \\
$\mathrm{SO}_{3}$ & 3.1 & 2.54 \\
$\mathrm{MgO}$ & 1.0 & 1.14 \\
Loss on ignition & 1.1 & 0.17 \\
\hline
\end{tabular}

Both crushed bricks and natural aggregates were sieved and the $12.70 \mathrm{~mm}(0.5 \mathrm{inch})$ size was used as the coarse aggregate size in the mixture design. Type I cement with the chemical and phase compositions shown in Table 1 was used in all concrete batches. The mixture proportions were determined by volume, with coarse aggregate composing $35 \%$, fine aggregate $25 \%$, and water-to-cement ratio of 0.42 . Three different mixtures were used in this study: (i) $100 \%$ natural 
granite aggregate (control), (ii) $25 \%$ crushed brick aggregate and $75 \%$ natural granite aggregate $(25 \% \mathrm{~B})$ and (iii) $50 \%$ crushed brick aggregate and $50 \%$ natural granite aggregate $(50 \% \mathrm{~B})$.

\section{Experimental setup and tests}

The specific gravity and the absorption of the aggregates were determined using the standard test method in ASTM C 127 [28]. The abrasion resistance of the coarse aggregates was also determined using the procedure in ASTM C 131 [29]. L.A. abrasion for small size coarse aggregates and aggregate gradation $\mathrm{C}$ was chosen.

Due to the high porosity and water absorption of the brick aggregates, it is suggested to soak the brick aggregates in water prior to adding to the concrete mixture $[16,18,30]$. Therefore, this procedure was adopted in this work for all course aggregates. Both natural and brick aggregates were soaked in water for 48 hours and added to the mixture in a saturated surface dry condition in order to maintain a constant w/c ratio. The fine aggregates were oven dried at $110^{\circ} \mathrm{C}$ for 48 hours prior to mixing and allowed to cool to room temperature. The w/c ratio was adjusted to consider the impact of water absorption by the fine aggregates. The concrete aggregates, cement, and water were then combined and mixed in a drum mixer in accordance with ASTM C $192[31]$.

The workability of fresh concrete was measured using the slump test, using ASTM C 143[32].

Three identical $100 \mathrm{~mm} \times 200 \mathrm{~mm}(4$-in $\times 8$-in) concrete cylinders from each mixture were cast and wet cured for 28 days and then their compressive strengths were determined using ASTM C 
39 [33]. The absorption of the bulk brick was also determined in accordance to ASTM C 67 [34].

$76.20 \mathrm{~mm} \times 76.20 \mathrm{~mm} \times 304.80 \mathrm{~mm}(3$-in $\times 3$-in $\times 12$-in) concrete prisms were cast, wet cured for 28 days and used for the freeze-thaw test, according to ASTM C 666 [35], procedure A.

Density, absorption, and voids of the hardened concrete samples were also determined using ASTM C 642 [18]. For this test, $100 \mathrm{~mm} \times 200 \mathrm{~mm}(4$-in $\times 8$-in) concrete cylinders from each mixture were cast and wet cured for 28 days. Then, sections with $50 \mathrm{~mm}$ (2-in) height were cut from each cylinder and used for the test.

$100 \mathrm{~mm} \times 200 \mathrm{~mm}$ concrete cylinders were used to measure the chloride penetration depth. For this purpose, 28 days after casting and curing, each cylinder was cut in half, and epoxy coated except the top and bottom surfaces. A reservoir was then constructed on the top of the cylinder halves out of aluminum tape, and the inside edges were coated with waterproof sealer to prevent leaks (Figure 2). $3 \% \mathrm{NaCl}$ solution was added to the reservoir and the samples were then subjected to two weeks wet-two week dry cycles. Each month, at the end of each dry cycle, three cylinders were split and the exposed surfaces were sprayed with $0.1 \mathrm{~N}$ silver-nitrate solution as an indicator to quantitative measure of the chloride penetration depth [36]. After 24 hours, the chlorides turned into a purple color, and the depth of penetration was recorded. 

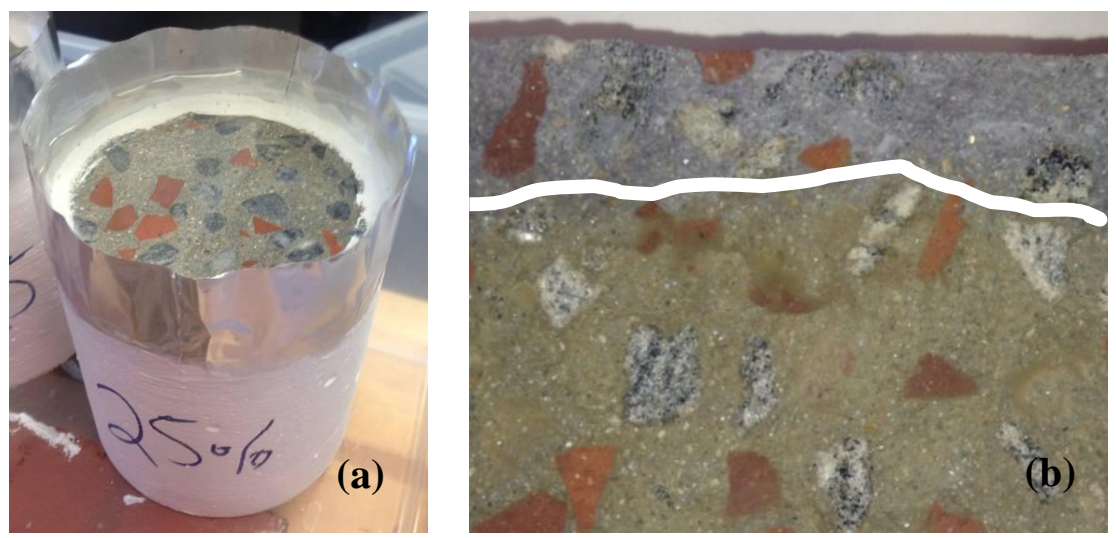

Figure 2. (a) One of the cylinders for measuring chloride penetration, with aluminum tape reservoir, and (b) chloride penetration after five months in one of the specimens with $25 \%$ brick as aggregates replacement

Rapid Chloride Permeability Test (RCPT) was also used on concrete cylinders, according to ASTM C1202 [37], to evaluate the resistance of each mixture against chloride penetration.

Another method that can be used to describe the behavior of different concrete mixtures is Electrical Impedance Spectroscopy (EIS). EIS technique has been shown to provide useful information that can be used to characterize cementitious systems [38-40]. For the measurement of electrical impedance, an automated program was used that measured the electrical resistance of the concrete between two steel rods at a given interval [41]. A total of three $100 \mathrm{~mm} \times 200$ mm cylinders were poured from each mixture. Two $7.93 \mathrm{~mm}(5 / 16$-in) threaded stainless steel rods were cast in each sample. These rods were placed at $76.20 \mathrm{~mm}$ (3-in) apart on-center, and $12.70 \mathrm{~mm}(0.5$-in) on-center from the sides. All samples were connected to the measuring system and measurements of the electrical resistance were started immediately after casting the samples, and ran every fifteen minutes for one week. After the first week, the measurements 
were carried out once every month for six months. The measured resistance values were then converted to resistivity [41]. The measurement frequency range that was used for the tests ranged from $1 \mathrm{MHz}$ to $10 \mathrm{~Hz}$ with ten measurements per decade using the $500 \mathrm{mV}$ AC stimulus.

A total of three corrosion samples (modified ASTM G 109 [42]) were cast and wet cured for 28 days. Instead of creating samples according to the standard and building a Plexiglas reservoir on the top, the reservoir was molded into the sample as shown in Figure 3. The ponding well was filled with a $3 \% \mathrm{NaCl}$ solution and the specimens were alternately exposed to 2-week periods with solution then 2 weeks without solution. The voltage drop across the $100 \mathrm{ohm}$ resistor was monitored monthly, after the first week of wet period, allowing the macro-cell corrosion current between the top (anode) bar and the bottom (cathode) bar to be determined using ohm's law. The measured corrosion current then divided by the exposed surface area of each rebar to calculate the corrosion current density. The half-cell potential values of the top bar in each sample were also measured versus $\mathrm{Cu} / \mathrm{CuSO}_{4}$ reference electrode with the same interval as the macro-cell corrosion current.
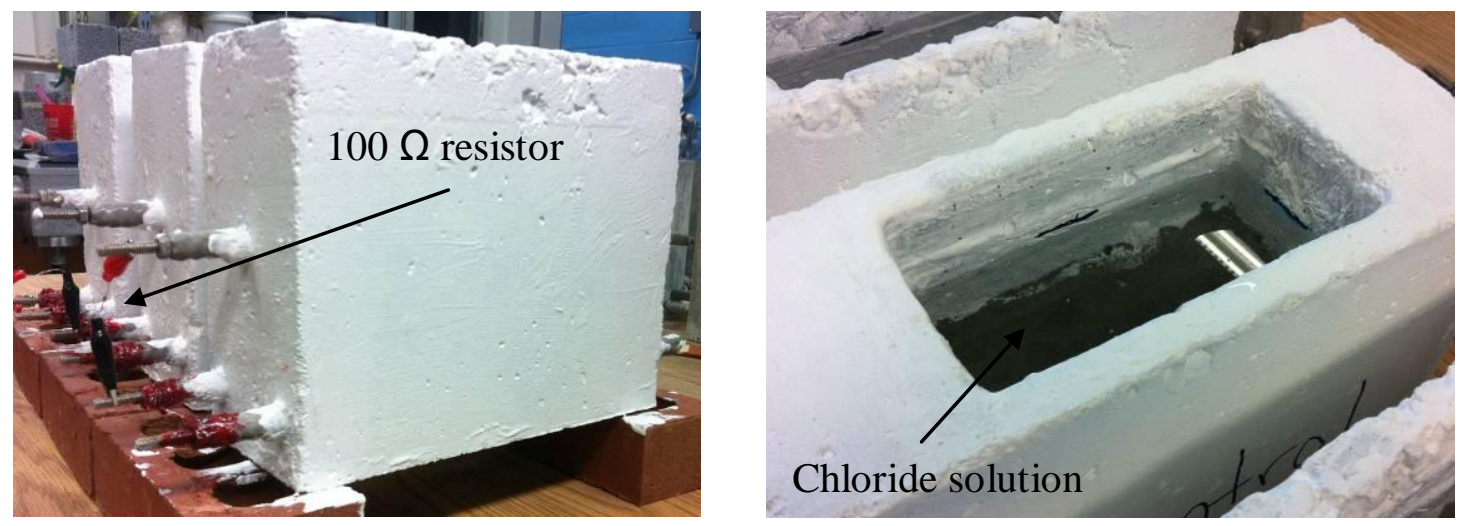

Figure 3. Corrosion samples using in this study 


\section{Results and discussion}

Figure 4 shows the microscopic images of the cut surface of concrete with natural and brick aggregates. From visual observation of the surface of concrete it seems that brick aggregates have more pores in their structure compared to that in natural aggregates.
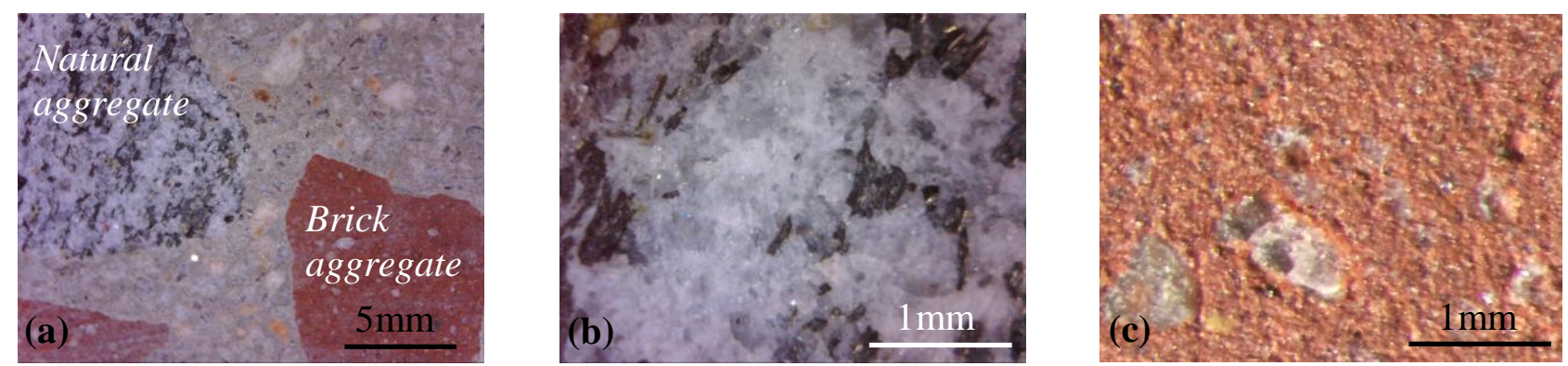

Figure 4. Image of the surface of concrete: (a) both natural and brick aggregates, (b) brick aggregate and (c) natural aggregate

To characterize the aggregates more accurately and to determine their physical properties and abrasion resistance, ASTM standard test methods were carried out on the samples and the results are showed in Table 2. 
Table 2. Physical properties of coarse aggregates

\section{Aggregate}

Test result

Natural Brick

$\begin{array}{lll}\text { Cold water absorption (\%) } & 0.95 & 1.79\end{array}$

Boiling water absorption (\%)

$\begin{array}{ll}--- & 1.80\end{array}$

$\begin{array}{lll}\text { Bulk specific gravity } & 2.46 & 2.31\end{array}$

$\begin{array}{lll}\text { Bulk specific gravity, SSD } & 2.48 & 2.40\end{array}$

$\begin{array}{lll}\text { Apparent specific gravity } & 2.52 & 2.54\end{array}$

L.A. Abrasion results for Coarse Aggregates

\section{Aggregate}

Test result

$100 \%$ natural

$25 \%$ brick

$50 \%$ brick

$100 \%$ brick

aggregate

$\begin{array}{lcccc}\text { L. A. abrasion loss (\%) } & 64.50 & 49.30 & 43.20 & 30.60 \\ \text { L. A. abrasion hardness } & 0.35 & 0.25 & 0.26 & 0.26\end{array}$

As can be seen in Table 2, both natural and crushed brick aggregates had similar specific gravities. However, the crushed brick aggregates had nearly twice the absorption of natural aggregates used in this study and were more porous. L.A. abrasion results shows that the natural aggregates used in this investigation were softer than the crushed brick aggregates. A lower hardness ratio correlates to an aggregate with a more uniform hardness. In this respect, brick aggregates had a more uniform hardness compared to than for natural aggregates from the upstate region of South Carolina. 
The workability of the fresh concrete was determined by the slump test and the results are shown in Table 3. As can be seen, with constant water to cement ratio, the workability of concrete increased with an increase in the amount of crushed brick as coarse aggregates. This could be attributed to more porosity of brick aggregates compared to that of the natural aggregates. More permeable aggregates can hold more water which in return improves workability in fresh concrete.

Table 3. Results of the slump test

\begin{tabular}{cc}
\hline Mixture & Slump (mm) \\
\hline Control (100\% natural aggregate) & 44.45 \\
$25 \%$ brick & 63.50 \\
$50 \%$ brick & 88.90 \\
\hline
\end{tabular}

The density, absorption, and voids of the hardened concrete specimens were measured and the test results are given in Table 4. From the table, it can be seen that the absorption and percentage of voids in all three mixtures are comparable. Table 4 also shows that with an increase in brick content, the density of the concrete decreases. 
Table 4. Density, absorption, and voids of hardened concrete

\begin{tabular}{|c|c|c|c|c|c|c|c|}
\hline $\begin{array}{c}\text { Sample } \\
\text { type }\end{array}$ & $\begin{array}{c}\text { Absorption } \\
\text { after } \\
\text { immersion } \\
(\%)\end{array}$ & $\begin{array}{c}\text { Absorption } \\
\text { after } \\
\text { boiling } \\
(\%)\end{array}$ & $\begin{array}{c}\text { Bulk } \\
\text { density, } \\
\text { dry } \\
\left(\mathrm{g} / \mathrm{mm}^{3}\right)\end{array}$ & $\begin{array}{c}\text { Bulk } \\
\text { density } \\
\text { after } \\
\text { immersion } \\
\left(\mathrm{g} / \mathrm{mm}^{3}\right)\end{array}$ & $\begin{array}{c}\text { Bulk } \\
\text { density } \\
\text { after } \\
\text { boiling } \\
\left(\mathrm{g} / \mathrm{mm}^{3}\right)\end{array}$ & $\begin{array}{r}\text { Apparent } \\
\text { density } \\
\left(\mathrm{g} / \mathrm{mm}^{3}\right)\end{array}$ & $\begin{array}{c}\text { Volume } \\
\text { of voids } \\
(\%)\end{array}$ \\
\hline Control & 7 & 8 & 2.24 & 2.40 & 2.41 & 2.68 & 16 \\
\hline $\begin{array}{l}25 \% \\
\text { brick }\end{array}$ & 8 & 7 & 2.16 & 2.31 & 2.32 & 2.55 & 15 \\
\hline $\begin{array}{l}50 \% \\
\text { brick }\end{array}$ & 8 & 8 & 2.11 & 2.27 & 2.28 & 2.53 & 17 \\
\hline
\end{tabular}

The results from the compressive strength test (Figure 5) showed that all mixtures passed the South Carolina Department of Transportation (SCDOT) specifications for bridge applications, with a target 28-day compressive strength of $27.6 \mathrm{MPa}(4,000 \mathrm{psi})$. The cylinders containing brick aggregates were slightly stronger on average than the control mixture and the strength increases by increasing the brick content which could be due to the relatively low strength of natural aggregates compare to that for brick aggregates, as determined by L.A. abrasion test. 


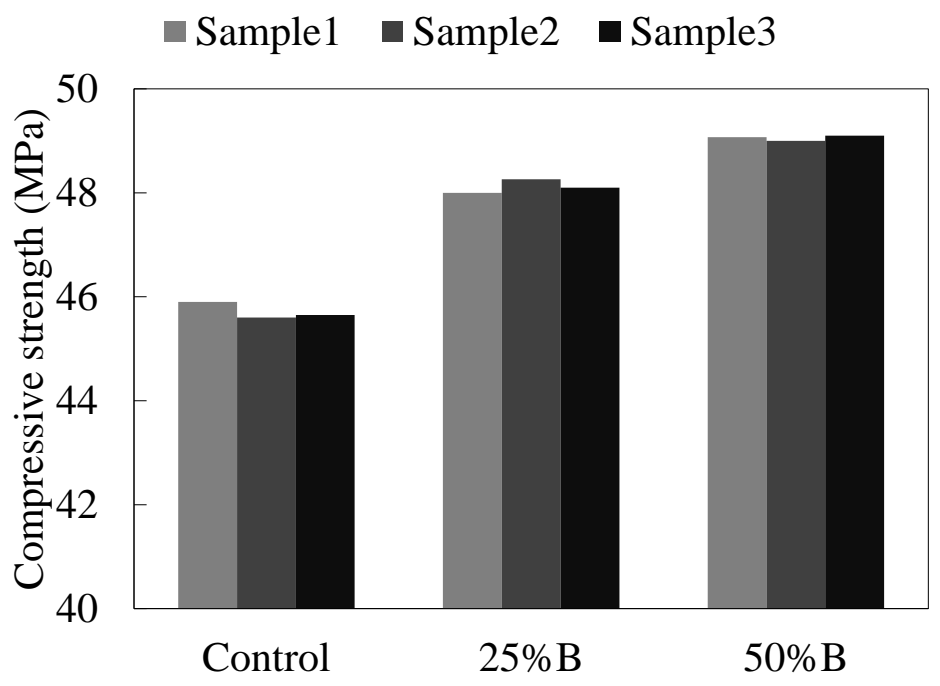

Figure 5. 28-day compressive strength of samples

The changes as a percentage of the original modulus of elasticity versus number of cycles for all samples during the freeze-thaw test are shown in Figure 6. 60\% of the initial modulus is the ASTM failure criterion and as can be seen, none of the samples failed within the 300 cycles. However, increasing the brick content increased the freeze-thaw resistance of the concrete. This could be attributed to more porosity in brick aggregates structure compared to that in natural aggregates.

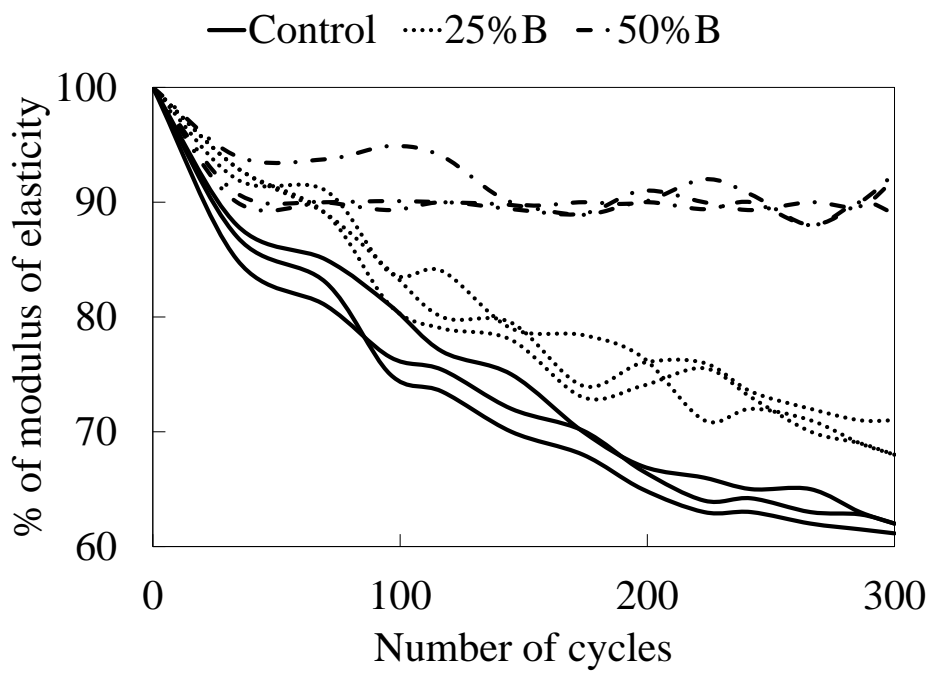

Figure 6. Change in modulus of elasticity in samples 
The depths of chloride penetration over time for all mixtures are shown in Figure 7. As can be seen, chloride penetration increased by increasing the brick content. This increase was approximately $16 \%$ and $24 \%$ for $25 \%$ and $50 \%$ brick replacements, respectively at six months of exposure to chloride solution and again could be attributed to the more porosity of brick aggregates compared to that in natural aggregates.

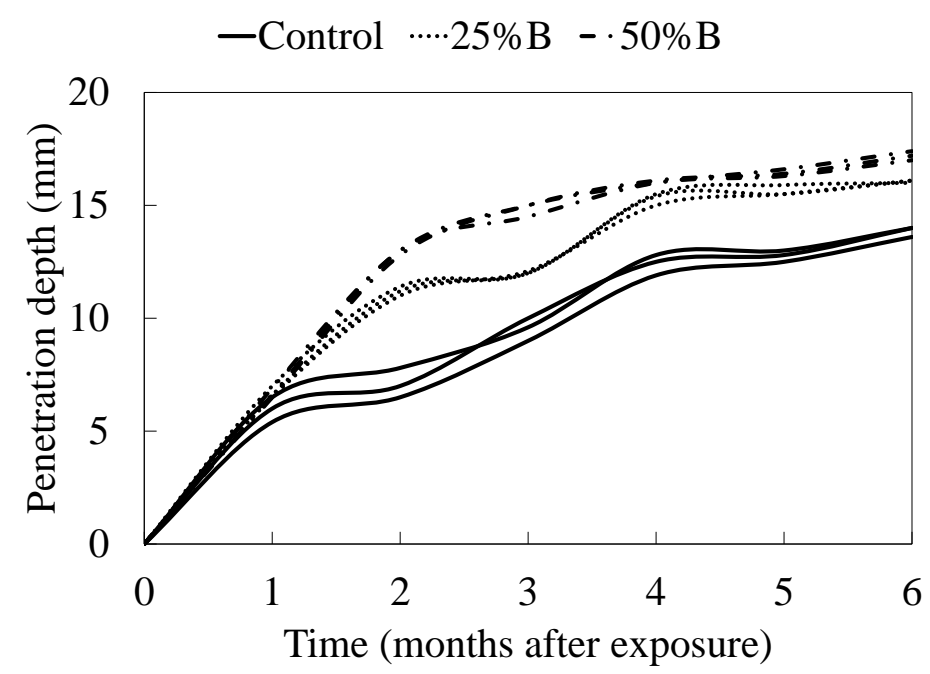

Figure 7. Chloride penetration depth during six months of exposure to $3 \% \mathrm{NaCl}$ solution

Figure 8 shows the change in electrical resistivity during six months of measurements. The resistivity of all samples increased sharply within the first 24 hour after casting due to hydration reactions and increased slowly after the first 24 hours. By increasing the brick content, the electrical resistance of the samples decreases. At the end of six months of measurements, concrete samples with $50 \%$ and $25 \%$ brick shows $16 \%$ and $10 \%$ decrease in their resistivity, respectively. Higher porosity in the samples with brick aggregates was the reason of such observation. This observation is in agreement with the chloride diffusion and absorption test of aggregates. 


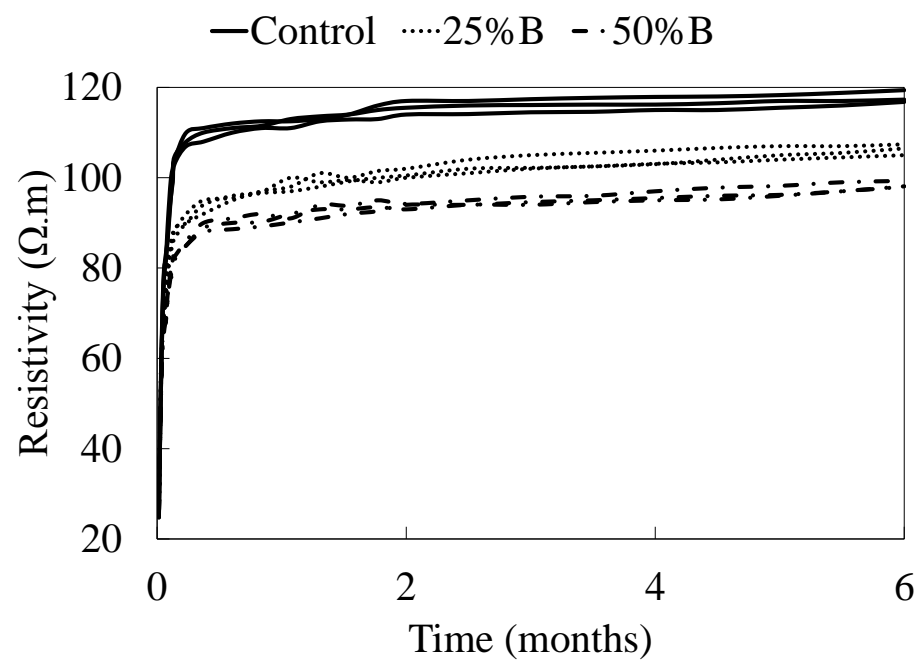

Figure 8. Electrical resistivity of concrete over time

The results of the RCPT are shown in Figure 9. As can be seen, by increasing the brick content in the mixture, the chloride penetration increased. This is in agreement with the previous results from aggregate absorption, chloride diffusion and change in electrical resistivity which was due to higher porosity in brick aggregates compared to that in natural aggregates.

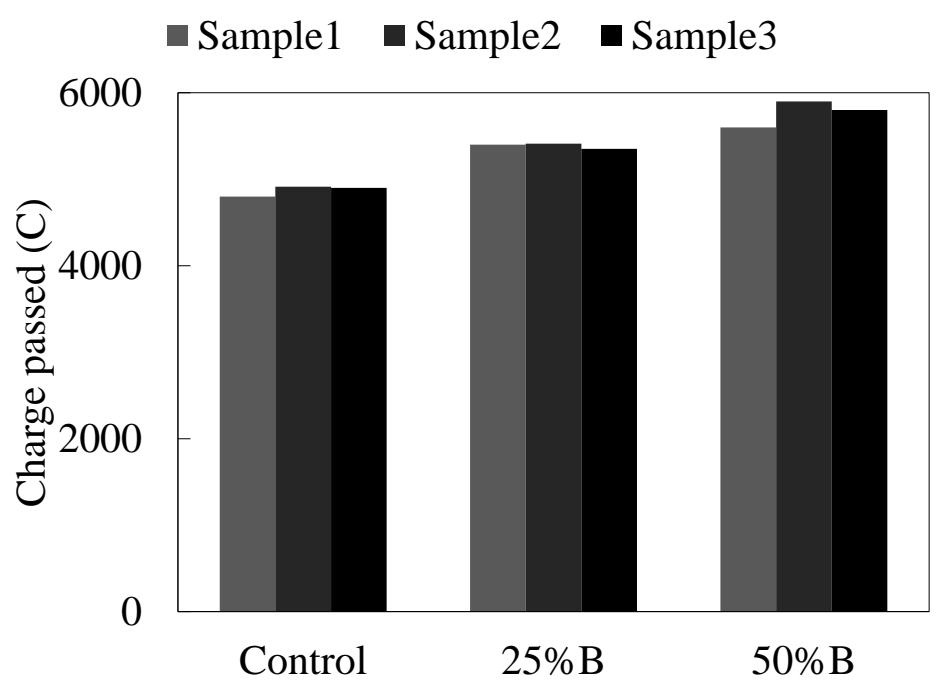

Figure 9. Results of the RCPT on all concrete mixture, 28 days after casting 
Figure 10, shows corrosion potential (half-cell potential) and corrosion current density values of samples with different percentages of brick as their coarse aggregates and natural aggregates during 34 months of exposure to $3 \% \mathrm{NaCl}$ solution. As it was expected from the results of the aforementioned tests, corrosion of steel in samples with $50 \%$ brick as their coarse aggregates started first and followed by the samples with $25 \%$ brick and samples with $100 \%$ natural aggregates. The drop in potential values corresponded well with the corrosion current density measurements. This observation was again attributed to the porosity of brick aggregates which enhanced the chloride penetration into concrete. Since active corrosion in control samples was recently initiated, the corrosion measurements will be continued. More detailed results which will include the results of other electrochemical measurements to reveal the mechanism of corrosion and visual observation of the rebars will be presented later. 

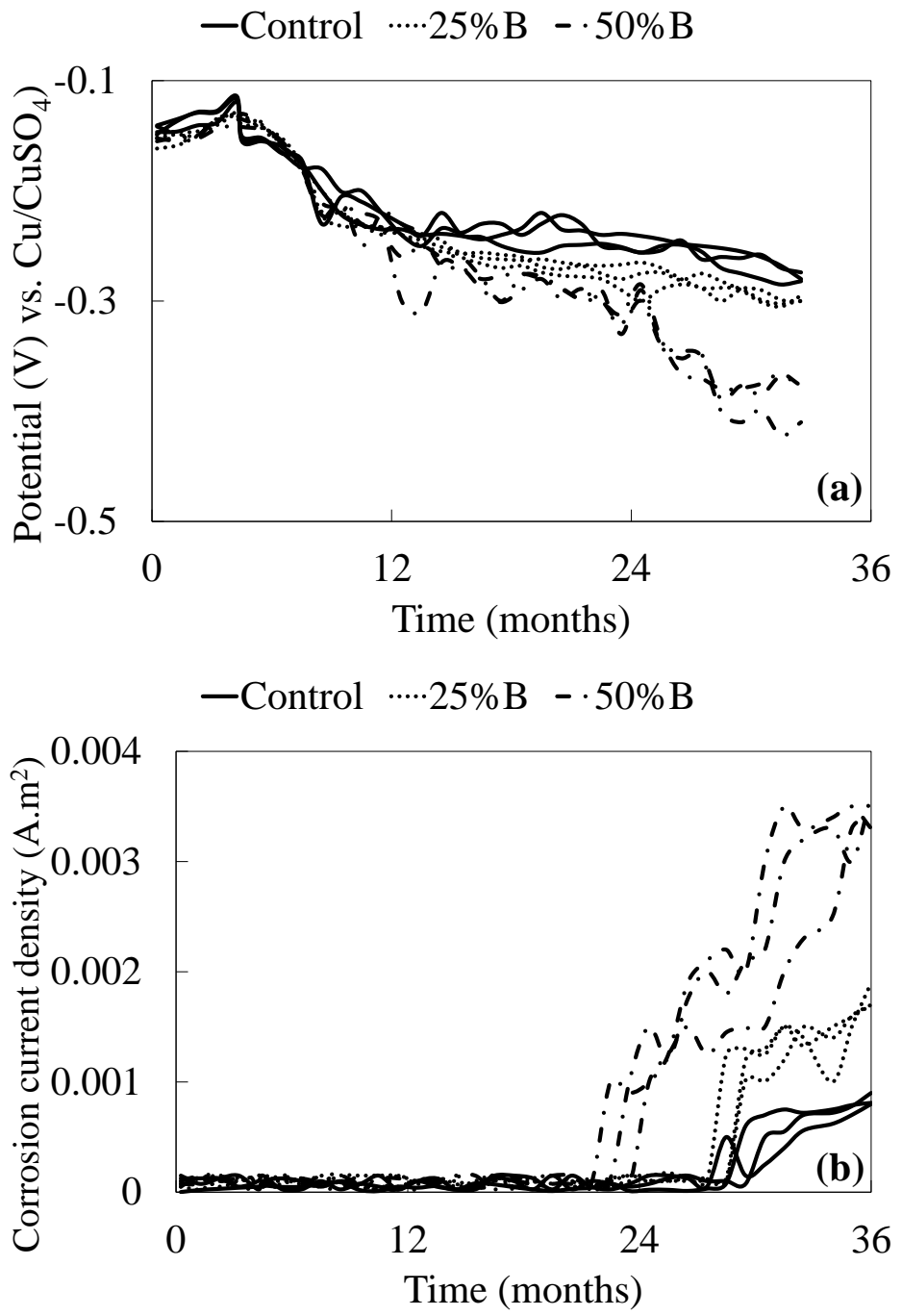

Figure 10. (a) Corrosion potential and (b) Corrosion current density of top rebar as a function of exposure time to $3 \% \mathrm{NaCl}$ solution.

\section{Summary and conclusion}

This paper studied the impact of partial replacement of natural coarse aggregates with crushed brick on the durability of concrete. Based on the data and results found in this study, it can be concluded that natural coarse aggregates can be replaced by crushed bricks, without significant 
change in the durability of concrete when the steel is not present. However, when concrete is reinforced with steel, replacing natural aggregates with crushed brick is not recommended.

The following conclusions can be made based on the observations and experimental results in this investigation:

1. Brick aggregates had a higher porosity and absorption than natural aggregates, thus precautions need to be made when mixing to account for the change in water demand and adjustment for $w / c$ ratio.

2. Concrete with brick aggregates showed an increase in its workability compared to that in concrete with natural aggregate. The improvement in workability enhanced with an increase in coarse brick aggregate content. This is attributed to more porous structure of brick aggregates compared to that in natural aggregates.

3. Concrete with brick aggregates showed slight improvement in compressive strength compared to that in concrete made with $100 \%$ natural aggregate. This increase in compressive strength is more profound when more natural aggregates are replaced with brick aggregates.

4. By increasing the brick content, the resistance to chloride penetration decreases. This could be attributed to the higher porosity and absorption in brick aggregates compared to those in natural aggregates.

5. All sample (with or without brick aggregates) were able to pass the 300 cycles of the freeze/thaw tests. However the samples with brick aggregates showed superior performance than the samples made with $100 \%$ natural aggregates. 
6. The electrical resistivity changed between the three types of concrete, with the control having the highest resistivity and the 50\% brick having the lowest resistivity. As it was expected, this correlated to an inverse relationship with the porosity of the concrete samples and chloride penetration test.

7. Corrosion of the reinforcing steel bars in samples containing brick as their coarse aggregates initiated before that in samples with natural aggregates. This observation indicated that increasing the brick content, reduced the time to corrosion initiation. This is a significant observation which needs to be considered when incorporating bricks as coarse aggregates in concrete.

\section{Acknowledgements}

This work was performed in Corrosion Research Laboratory (CorRLab) at Clemson University. Support for this project was provided by the Glenn Department of Civil Engineering at Clemson University. The authors would like to acknowledge the support that has made these laboratories and this research possible. The first and the third author of this paper were in part supported by National Science Foundation (Grant \# 1011478) which is greatly acknowledged. Any opinions, findings, and conclusions or recommendations expressed in this material are those of the author and do not necessarily reflect the views of the National Science Foundation. 


\section{References}

1. $\quad$ Broviak, P., Managing C\&D Debris. Public Works, 2005. 136(2): p. 29-31.

2. Page, I., The rise and fall of claddings. Build, 2007. June-July: p. 68-69.

3. Scoping study to investigate measures for improving the environmental sustainability of building materials. 2006, Centre for Design at RMIT University, Melbourne in association with BIS, Shrapnel, CSIRO,Deni Greene Consulting Services,Syneca Consulting p. 271.

4. Crowther, P., Building deconstruction in Australia, in Overview of deconstruction in selected countries, CIB Report No. 252, C. J. Kibert and R. A. Chini, Editors. 2000. p. 28.

5. Formoso, C.T., Soibelman, L., Cesare, C.D., and Isatto, E.L., Material waste in building industry: main causes and prevention. Journal of Construction and Engineering and Management, 2002. July-August: p. 316-325.

6. Demir, I. and Orhan, M., Reuse of waste bricks in the production line. Building and Environment, 2003. 38: p. 1451-1455.

7. Lennon, M., Recycling Construction and Demolition Wastes, A Guide for Architects and Contractors. 2005.

8. Etxeberria, M., Recycled Aggregate Concrete as Structural Material. Materials and Structures, 2007. 40(5): p. 529-541.

9. Canonico, D.A., Griess, J.C., and Robinson, G.C., Final report on PCRV thermal cylinder axial tendon failures. 1976, Oak Ridge National Laboratory.

10. DeVenny, A. and Khalaf, F.M., The use of crushed brick as coarse aggregate in concrete. Masonry International, 1999. 12: p. 81-84. 
11. Hansen, T.C., Recycling of demolished concrete and masonry, in Report of Technical Committee 37-DRC, Demolition and Reuse of Concrete. 1992, RILEM: E\&FN Spon, London.

12. London, E. and Spoon, F.N., Recycling of demolished concrete and masonry, T. C. Hansen, Editor. 1992, RILEM.

13. Venta, G.J., Life cycle analysis of brick and mortar products. 1998, ATHENA Sustainable Materials Institute: Ottawa, Canada.

14. Lalchandani, D. and Maithel, S., Towards cleaner brick ilns in India: a win-win approach based on zigzag firing technology. 2013, A Shakti Sustainable Energy Foundation Supported Initiative, ADCS (Academic and Development Communication Services): Chennai. p. 22.

15. Debeib, F. and Kenai, S., The use of coarse and fine crushed bricks as aggregate in concrete. Construction and Building Materials, 2008. 22: p. 886-893.

16. Khalaf, F.M., Properties of New and Recycled Clay Brick Aggregates for Use in Concrete. Journal of Materials in Civil Engineering, 2005(July/August 2005): p. 456-464.

17. Suzuki, M., Meddah, M.S., and Sato, R., The use of coarse and fine crushed bricks as aggregate in concrete. Construction and Building Materials, 2008. 22: p. 886-893.

18. Khalaf, F.M., Using Crushed Clay Brick as Coarse Aggregate in Concrete. Journal of Materials in Civil Engineering, 2006(July/August 2006): p. 518-526.

19. Dabieb, F., The Use of Coarse and Fine Crushed Bricks as Aggegate in Concrete. Construction and Building Materials, 2007: p. 886-893.

20. Akhtaruzzaman, A.A., Properties of Concrete Using Crushed Brick as Aggregate. Concrete International, 1983(February 1983): p. 58-63. 
21. Litvan, G.G. and Sereda, P.J., Particulate admixture for enhanced freeze-thaw resistance of concrete. Cement and Concrete Research, 1977. 8(1): p. 53-60.

22. Bektas, F., Wang, K., and Ceylan, H., Effects of crushed clay brick aggregate on mortar durability. Construction and Building Materials, 2009. 23: p. 1909-1914.

23. Mulheron, M. and O'Mahony, M., The durability of recycled aggregates and recycled aggregate concrete. Second RILEM International Symposium On Demolition and Reuse of Concrete and Masonry, 1988. 2: p. 633-642.

24. Mulheron, M. and O'Mahony, M., Properties and performance of recycled aggregates. Highways and Transportation, 1990. 37(2): p. 35-37.

25. Montemor, M.F., Simoes, A.M.P., and Ferreira, M.G.S., Chloride-induced corrosion on reinforcing steel: from the fundamentals to the monitoring techniques. Cement \& Concrete Composites, 2003. 25.

26. Kibriya, T. and Speare, P. The use of crushed brick coarse aggregate in concrete. in Concrete in the Service of Mankind. 1996. London: RILEM.

27. Cavalline, T.L., Recycled brick masonry aggregate concrete: use of recycled aggregates from demolished brick masonry construction in structural and pavement grade portland cement concrete. $\mathrm{PhD}$ thesis in Civil Engineering, University of North Carolina at Charlotte, 2012.

28. ASTM, ASTM C127, 2012, "Standard Test Method for Density, Relative Density (Specific Gravity), and Absorption of Coarse Aggregate". 2012, ASTM International: West Conshohocken, PA. 
29. ASTM, A240/A240M-06b: Standard Specification for Chromium and Chromium-Nickel Stainless Steel Plate, Sheet, and Strip for Pressure Vessels and for General Applications. 2006: Philadelphia, PA.

30. Cachim, P.B., Mechanical properties of brick aggregate concrete. Construction and Building Materials, 2009. 23: p. 1292-1297.

31. ASTM, ASTM C192 / C192M: Standard practice for making and curing concrete test specimens in the laboratory. 2007.

32. ASTM, ASTM C143, 2010a, "Standard Test Method for Slump of Hydraulic-Cement Concrete". 2010, ASTM International: West Conshohocken, PA.

33. ASTM, ASTM C39, 2012, "Standard Test Method for Compressive Strength of Cylindrical Concrete Specimens". 2012, ASTM International: West Conshohocken, PA.

34. Rafsanjani, H.N., Chehreghani, M., and Norubakhsh, M., Recycling of crushed clay brick as aggregate in concrete. Applied Mechanics and Materials, 2011. 94-96: p. 1087-1090.

35. ASTM, ASTM C666, 2003 (2008), "Standard Test Method for Resistance of Concrete to Rapid Freezing and Thawing". 2008, ASTM International: West Conshohocken, PA.

36. Otsuki, N., Sagataki, S., and Nakashita, K., Evaluation of AgNO3 solution spray method for measurement of chloride penetration into hardened cementitiuos matrix materials. ACI Materials Journal, 1992. 89(6): p. 587-592.

37. ASTM, C1202: Standard Test Method for Electrical Indication of Concrete's Ability to Resist Chloride Ion Penetration. 2012.

38. Christensen, B.J., Coverdale, R.T., Olson, R.A., Ford, S.J., Garboczi, E.J., Jennings, H.M., and Mason, T.O., Impedance Spectroscopy of Hydrating Cement-Based Materials: 
Measurement, Interpretation, and Application. Journal of American Ceramic Society, 1994. 77(1): p. 2789-2801.

39. Gu, P., Xie, P., and Beaudoin, J.J., Some applications of AC impedance spectroscopy in cement research. Cement, Concrete and Aggregates, 1995. 17(2): p. 113-118.

40. McCarter, W.J., Chrisp, T.M., Starrs, G., and Blewett, J., Characterization and monitoring of cement-based systems using intrinsic electrical property measurements. Cement and Concrete Research, 2003. 33: p. 197-206.

41. Poursaee, A. and Weiss, W.J., An Automated Electrical Monitoring System (AEMS) to Assess Property Development in Concrete. Automation in Construction, 2010. 19: p. 485490.

42. ASTM G109-02, Standard Test Method for Determining the Effect of Chemical Admixtures on the Corrosion of Embedded Steel Reinforcement in Concrete Exposed to Chloride Environments. 1992, American Society for Testing Materials: West Conshocken, PA. p. 451-455. 